\title{
伝達マトリックス法による曲線 I 形ばりの耐荷力解析 ULTIMATE STRENGTH ANALYSIS OF CURVED I-BEAMS BY TRANSFER MATRIX METHOD
}

\author{
前川幸 次* ・吉田博** \\ By Kouji MAEGAWA and Hiroshi YOSHIDA
}

\section{1. 緒言}

薄肉曲線ばりが構造要素として使用される機会はしだ いに多くなり, その力学的挙動の解析も多くの研究者に よって行われている，西野らは有限変位のひずみ一変位 関係式をもとに仮想仕事の原理と変分法を応用して薄肉 直線ばりの支配方程式が数学的演算のみで導けることを 文献 1）に示し，その手法を用いて文献 2) では，微小 変位理論における薄肉円弧曲がりばりの静的挙動の定式 化を行っている．また，遠田 ${ }^{3)}$ は変位の微小増分を考慮 したつり合い条件式から薄肉開断面曲線ばりの基礎微分 方程式を導いている.さらに，薄木ら ${ }^{4), 7)}$ は薄肉回転シ ェルの非線形のひずみ-変位関係式をもとに薄肉曲線部 材の変形解析を剛性法による有限変位解析として行い, その曲げねじり現象について考察している.

しかしながら，これまでは厳密な支配方程式を導くこ とに力点が置かれてきたように思われる．曲線ばりでは 鉛直荷重だけを受けても曲率に起因するねじりおよび曲 率方向への変位が生じるらえに，その応力分布特性から 通常の 1 軸あるいは 2 軸対称断面部材であっても断面の 塑性化に伴ら未降伏断面の非対称化が生ずる. 曲線ばり に対して安全性を確保した設計を行うためには，幾何学 的非線形性のみならず材料的非線形性を考慮した解析を 行い, 曲線ばりの耐荷力について把握しておく必要があ る.

本研究では，まず，遠田の方法 ${ }^{3)}$ を用いて曲線 I 形ば りの非弾性状態を考慮した基礎微分方程式を導き，はり の非弾性解析に対する有効性をかんがみて伝達マトリッ クス法を用いて数值解析を行らための定式化を行う. 次 に, 得られた数值解析プログラムの妥当性を実験值 ${ }^{15)}$ と

\footnotetext{
* 正会員 工修 国立石川工業高等専門学校講師 土木工学 科

** 正会員 工博 金沢大学教授 工学部土木工学科
}

の比較により検討したうえで，曲線 I 形ばりの耐荷力曲 線の性状および而荷力に及ぼす残留応力の影響について の検討を行う.

\section{2. 解 析 法}

本研究においては，前述のように曲線ばりの材料非線 形性を考慮した有限変位理論による基礎微分方程式に伝 達マトリックス法を用いて解析する．本文では紙面の都 合上，格間伝達マトリックスと格点伝達マトリックスの 誘導過程を示す.ここに格間伝達マトリックスとは, 曲 線ばりを長さ方向に分割して得られる円弧要素（格間） の両端における状態量を結ぶマトリックスであり, 分割 点（格点）の両側における状態量を結ぶものを格点伝達 マトリックスといら.

\section{（1）仮定}

(1) 部材は水平面内のみに一定の曲率を有する薄肉曲 線 I 形ばりであり，横断面の図心を通る母線の曲率 半径は $R$ である.

(2) 横断面形状は部材軸方向に一定であり, 曲率半径

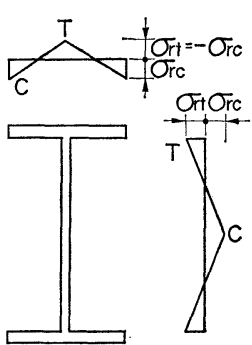

Pattern I (For Rolled Beams) $T$ : Tension, $C$ : Compression ----Small Rectangular Elements

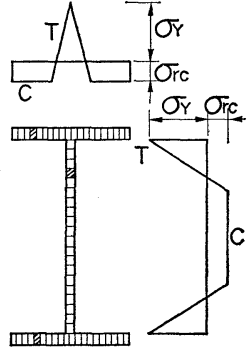

Pattern II (For Built-up Beams)
図一1 残留応力分布および微小断面要素 
方向の断面寸法は曲率半径に比べて十分小さい．ま た，はりを構成する母線ごとの曲率の差は無視す る.

(3) 横断面の形状は変形後も不変である

(4) 残留応力の分布型は直線ばりに用いられているも のを適用し，部材軸接線方向にのみ存在し板厚方向 には一定である（図一1）。また，初期不整としての 残留応力は自己つり合いを保つものとする注 1).

(5) 図一1 に示す微小断面要素の図心におけるひずみ $\varepsilon_{i}$ (残留ひずみを含む) が降伏ひずみ $\varepsilon_{Y}$ を超えた とき，その要素は降伏したものとする.

(6) 格間においては, 部材軸方向に断面の降伏部分は 一定であり，したがって弾性域にとどまっている残 された部分（以後，弾性核とよぶ）湾化しない，

(7) 材料は完全弾塑性体である。また，除荷は起こら ないものとする.

(8) 弾塑性域における曲げ剛性およびそりねじり剛性 は弾性核のみ有効であるとし，St. Venant のねじ り剛性䋲塑性域でも全断面有効とする ${ }^{10)}$.

(9) 断面定数はいずれも曲率の影響(1),2),4)を無視す る.

\section{（2）格間伝達マトリックス}

図一2 のように曲率半径 $R$ を有する円曲線ばりの微 小要素を考え, 図心 $D$ を原点とし, 曲率半径方向に $Y$ 軸 を一致させた直交曲線座標 ( $X-Y-Z$ 座標)，および弾 性核の図心 $\mathrm{C}$ を原点とし，弾性核の主軸を $y-z$ 軸とし た変形前の座標 $(x-y-z$ 座標) を設定する.図中, $\beta$ は $Y$ 軸と $y$ 軸のなす角 ( $x$ の正の方向に向かって時計回 りを正とする）であり， $Y_{c}$ および $Z_{c}$ は図心 C の $Y-Z$ 座標值である. はりの微小要素の原点 $\mathrm{C}$ を通る母 線の弧長 $d S$ とその中心角 $d \propto$ は $d S=\left(R-Y_{c}\right) d \alpha$ の 関係があり, $I d S, \Psi d S, \Omega d S$ および $\theta d S$ をそれぞれ $d S$ 間における点 $\mathrm{C} の ~ x, y, z$ 方向の変位増分および ねじり角の増分とすれば文献 5) の式 (6.1) に座標変換 を行い次のように表わせる.

$$
\left.\begin{array}{l}
\text { II } S=\left\{u^{\prime}-(v \cos \beta-w \sin \beta) /\left(R-Y_{c}\right)\right\} d S \\
\Psi d S=\left\{v^{\prime}+u \cos \beta /\left(R-Y_{c}\right)\right\} d S \\
\Omega d S=\left\{w^{\prime}-u \sin \beta /\left(R-Y_{c}\right)\right\} d S \\
\Theta d S=\left\{\theta^{\prime}+\left(v^{\prime} \sin \beta+w^{\prime} \cos \beta\right) /\left(R-Y_{c}\right)\right\} d S
\end{array}\right\}
$$

$(1 \cdot a \sim d)$

注 1）残留応力は直線ばりと同様，次式を満足するものとす る.

$$
\int_{F} \sigma_{r} d F=\int_{F} \sigma_{r} y d F=\int_{F} \sigma_{r} z d F=0
$$

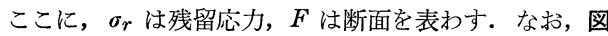
一1 の上らな残留応力分布を仮定すると，必然的に条件 式 $\left(\int_{F} \sigma_{r} \varphi_{c} d F=0\right)$ が成立する.
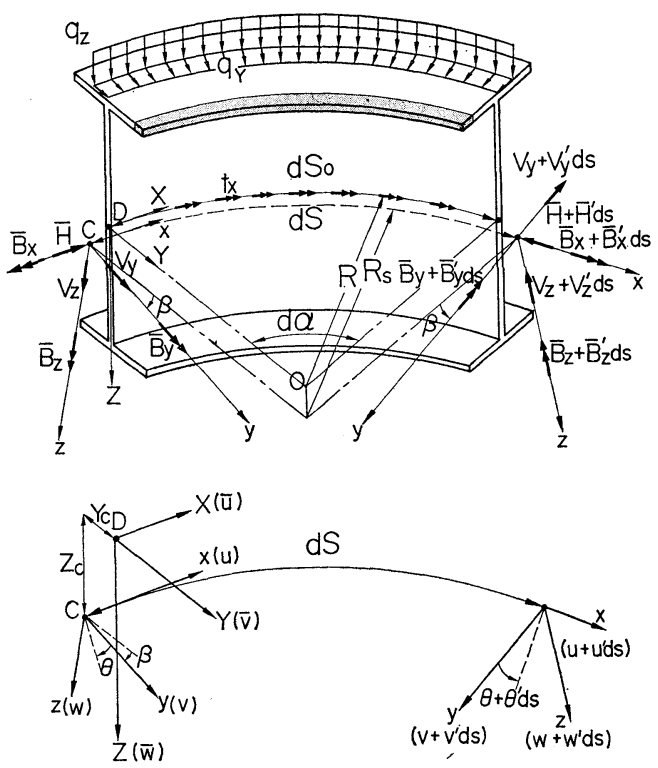

図一2 曲線 I 形ばりの断面力と変形量

ここに, $u, v, w$ および $\theta$ はそれぞれ弾性核の図心 $\mathrm{C}$ の $x, y, z$ 方向の変位および断面回転角であり, ()$^{\prime}=$ $d() / d S$ とする. なお, 以後, 仮定 (2) より $R-Y_{c} \fallingdotseq$ $R$ とする.

横断面上の任意の点 $\mathrm{A}(y, z)$ に扝ける $x, y$ およ び $z$ 方向の変位は仮定 (3) から次のよらに表わされ $る^{6)}$, 注 2).

$$
\left.\begin{array}{l}
u_{A}=u-\Psi y-\Omega z-\Theta \varphi_{c} \\
v_{A}=v-\theta z, w_{A}=w+\theta y
\end{array}\right\}
$$

ここに， $\varphi_{c}$ は弾性核の図心に関するそり関数であ る注 3 )。な打，式 (2) には変位の 2 次的成分は含まれて いないが，力のつり合い条件式において変位の微小増分 を考慮することにより線形化有限変位理論による解析を 行 $^{32,8)}$.

横断面上の任意点の垂直ひずみ $\varepsilon_{A}$ は式 (2) を用いて 次のように表わされる.

$$
\left.\begin{array}{rl}
\varepsilon_{A} & =d u_{A} / d S_{A}-\left(v_{A} \cos \beta-w_{A} \sin \beta\right) d \alpha / d S_{A} \\
d S_{A} & =\left(R-Y_{c}-y \cos \beta+z \sin \beta\right) d \alpha
\end{array}\right\}
$$

仮定 (2)より母線ごとの曲率の差を無視すれば， $d S_{0} \fallingdotseq d S \fallingdotseq d S_{A} \fallingdotseq R \cdot d \alpha,()^{\prime}=d() / d S_{0}$

となり，ここに， $d S_{0}$ は全断面の図心 D を通る母線の 微小円弧長である.

注 2）部材軸方向の剛体変位は横断面上ですべて原点 $\mathrm{C}$ の変 位 $u$ に等しいものとする7゙.

3）断面の降伏部分もそりは連続している.したがって, 降伏部分については板厚 $t=0$ の仮想板で置き換えて, 降伏部分のそり関数を算定する ${ }^{1,2)}$. 
圧縮を正とする残留ひずみ $\varepsilon_{r}=\varepsilon_{r}(y, z)$ を式 (3) に 加えて, 式 (1) および (2) を代入すると, 垂直ひずみ $\varepsilon$ は次式で表わされる.

$$
\varepsilon=\Pi-\Psi^{\prime} y-\Omega^{\prime} z-\Theta^{\prime} \varphi_{c}+(z \cos \beta+y \sin \beta) \theta / R
$$

$$
-\varepsilon_{r}
$$

ここで, 各格間の弾性核の決定は次のように行う.

まず，断面を構成する薄板（フランジおよびウェブ） を板幅方向に微小分割し (図一1 参照)，その微小断面 要素の図心における垂直ひずみ $\varepsilon_{i}$ を式 (5) より求め る. な押，式 (5) における変形量は格間の両端における 平均值を用い，得られるひずみ $\varepsilon_{i}$ は格間内で一定であ ると仮定する．次に，得られたひずみ $\varepsilon_{i}$ と降伏ひずみ $\varepsilon_{Y}$ を比較して, $\left|\varepsilon_{i}\right|<\varepsilon_{Y}$ であるときその微小断面要素 は弾性核の一部を構成するものとする. この操作は 図 -4 に括ける (9), (10), (11) に相当する.

得られた弾性核について断面定数を次のように定義す る.

$$
\left.\begin{array}{lll}
F_{e}=\int_{e} d F, & I_{y}=\int_{e} z^{2} d F, & I_{z}=\int_{e} y^{2} d F \\
I_{c}=\int_{e} \varphi_{c}^{2} d F, & R_{y}=\int_{e} \varphi_{c} z d F, & R_{z}=\int_{e} \varphi_{c} y d F
\end{array}\right\}
$$

ここに, 記号 $\int_{e}() d F$ は弾性核についての積分を意味 し，曲率の影響は無視する。

弾性核のせん断中心の $y$ および $z$ 座標をそれぞれ $y_{m}$ および $z_{m}$ とすると, $y$ および $z$ 軸が主軸であることお よび $\varphi_{c}$ は正規化したそり関数であることから次式が成 立する ${ }^{9}$.

$$
\left.\begin{array}{l}
y_{m}=R_{y} / I_{y}, \quad z_{m}=-R_{z} / I_{z}, \quad \int_{e} y d F=0 \\
\int_{e} z d F=0, \quad \int_{e} y z d F=0, \quad \int_{e} \varphi_{c} d F=0
\end{array}\right\}
$$

$x-y-z$ 座標に対応させて, 曲線ばりの変形後の状態 に対する直交曲線座標 $\xi-\eta-\zeta$ を定めて, この座標に関 寸る全断面について求めた断面力を $\bar{H}, \bar{B}_{\xi}, \bar{B}_{\eta}, \bar{B}_{\xi}, \bar{B}_{w}$ とする. ここに, 断面の降伏部分は降伏応力 $\sigma_{Y}$ に相当 する軸方向力を負担するものとし, $\bar{H}$ は軸方向力, $\bar{B}_{\xi}$, $\bar{B}_{\eta}$ および $\bar{B}_{\zeta}$ はそれぞれ $\xi$ 軸まわりのねじりモーメン ト， クおよび $\zeta$ 軸まわりの曲げモーメントであり， $\bar{B}_{w}$ はバイモーメントであり，Eをヤング率として次式で 表わせる。

$$
\begin{aligned}
\bar{H} & =-\int_{e} E \varepsilon d F-\int_{P} \sigma_{Y} \operatorname{sgn}(\varepsilon) d F \\
& =\left[-E F_{e} \Pi\right]+\left[-\int_{P}\left\{\sigma_{Y} \operatorname{sgn}(\varepsilon)+E \varepsilon_{r}\right\} d F\right] \\
& =[H]+[\Delta H] \\
\bar{B}_{\eta} & =-\int_{e} E \varepsilon z d F-\int_{P} \sigma_{Y} \operatorname{sgn}(\varepsilon) z d F
\end{aligned}
$$

$$
\begin{aligned}
= & {\left[E I_{y}\left(\Omega^{\prime}+\Theta^{\prime} y_{m}-\theta \cos \beta / R\right)\right] } \\
& +\left[-\int_{P}\left\{\sigma_{Y} \operatorname{sgn}(\varepsilon)+E \varepsilon_{r}\right\} z d F\right] \\
= & {\left[B_{\eta}\right]+\left[\Delta B_{\eta}\right] } \\
\bar{B}_{\zeta}= & \int_{e} E \varepsilon y d F+\int_{P} \sigma_{Y} \operatorname{sgn}(\varepsilon) y d F \\
= & {\left[-E I_{z}\left(\Psi^{\prime}-\Theta^{\prime} z_{m}-\theta \sin \beta / R\right)\right] } \\
& +\left[\int_{P}\left\{\sigma_{Y} \operatorname{sgn}(\varepsilon)+E \varepsilon_{r}\right\} y d F\right] \\
= & {\left[B_{\zeta}\right]+\left[\Delta B_{\zeta}\right] } \\
\bar{B}_{w}= & \int_{e} E \varepsilon \varphi_{c} d F+\int_{P} \sigma_{Y} \operatorname{sgn}(\varepsilon) \varphi_{c} d F \\
= & {\left[-E I_{c} \Theta^{\prime}+E I_{z} \cdot z_{m}\left(\Psi^{\prime}-\theta \sin \beta / R\right)\right.} \\
& \left.-E I_{y} y_{m}\left(\Omega^{\prime}-\theta \cos \beta / R\right)\right] \\
& +\left[\int_{P}\left\{\sigma_{Y} \operatorname{sgn}(\varepsilon)+E \varepsilon_{r}\right\} \varphi_{c} d F\right] \\
= & {\left[B_{w}\right]+\left[\Delta B_{w}\right] }
\end{aligned}
$$

ここに, 各定義式の右辺第 1 項の $\varepsilon$ には式 (5), (6) お よび（7）を用いた. 記号 $\int_{P}() d F$ は断面の降伏部分 についての積分であり, $\operatorname{sgn}(\varepsilon)$ は $\varepsilon$ が引張ならば 1 , 圧縮ならば -1 である. なお, 各式の右辺の第 2 式お よび第 3 式は []で区切られた第 1 項および第 2 項が それぞれ対応しており，便宜上，“弾性項”および“非弾 性項”とよぶことにする.

一方, ねじりモーメント $\bar{B}_{\xi} は$ St. Venant のねじり モーメント $B_{1}$, そり拘束による 2 次的ねじりモーメン 卜 $B_{2}$ および垂直応力 $\sigma$ のねじり変形に伴う分力によ るねじりモーメント $B_{3}$ の和として得られる ${ }^{3)}$.

$$
\begin{aligned}
B_{1}= & G K_{T} \Theta \\
B_{2}= & d \bar{B}_{w} / d S_{0} \\
= & -E I_{c} \Theta^{\prime \prime}-y_{m} E I_{y}\left(\Omega^{\prime \prime}-\theta^{\prime} \cos \beta / R\right) \\
& +z_{m} E I_{z}\left(\Psi^{\prime \prime}-\theta^{\prime} \sin \beta / R\right) \\
B_{3}= & \int_{e} E \varepsilon\left(y^{2}+z^{2}\right) \Theta d F+\int_{P} \sigma_{Y} \operatorname{sgn}(\varepsilon) \\
& \cdot\left(y^{2}+z^{2}\right) \Theta d F
\end{aligned}
$$

ここに, $G K_{T}$ は St. Venant の㸚じり剛性であり弾塑 性域でも全断面有効とする ${ }^{10)}$.また， $\Theta$ は仮定 (2)より 断面内で一定とする.

収束計算における 1 回前に得られた状態量を式 (16) に代入して得られる $I, \Psi^{\prime} ， \Omega^{\prime}$ および $\Theta^{\prime}$ を式 (5) に 用いて式 $(9 \cdot \mathrm{c})$ を線形化すると， $\bar{B}_{\hat{\xi}}$ は次式のように表 わされる。

$$
\begin{aligned}
& \bar{B}_{\xi}=\left[-E I_{c} \theta^{\prime \prime}-y_{m} E I_{y}\left(\Omega^{\prime \prime}-\theta^{\prime} \cos \beta / R\right)\right. \\
& \left.+z_{m} E I_{z}\left(\Psi^{\prime \prime}-\theta^{\prime} \sin \beta / R\right)+C_{T} \Theta\right] \\
& +\left[\Theta \int_{P} \sigma_{Y} \operatorname{sgn}(\varepsilon)\left(y^{2}+z^{2}\right) d F\right] \\
& =\left[B_{\xi}\right]+\left[\Delta B_{\xi}\right]
\end{aligned}
$$




$$
\begin{aligned}
C_{T}= & A_{1} r_{c}-A_{2} \gamma_{z}-A_{3} r_{y}-A_{4} \gamma_{\varphi} \\
& -E \int_{e} \varepsilon_{r}\left(y^{2}+z^{2}\right) d F+G K_{T} \\
r_{c}= & \int_{e}\left(y^{2}+z^{2}\right) d F, r_{y}=\int_{e} z\left(y^{2}+z^{2}\right) d F \\
r_{z}= & \int_{e} y\left(y^{2}+z^{2}\right) d F, r_{\varphi}=\int_{e} \varphi_{c}\left(y^{2}+z^{2}\right) d F \\
A_{1}= & -N / F_{e} \\
A_{2}= & -C_{1} M_{z}-\left(y_{m} z_{m} M_{y}+z_{m} M_{w}\right) / I_{\omega} \\
& +\left(C_{1} M_{y}-y_{m} z_{m} M_{z} / I_{\omega}\right) \phi \\
A_{3}= & C_{2} M_{y}+\left(y_{m} z_{m} M_{z}+y_{m} M_{w}\right) / I_{\omega} \\
& +\left(C_{2} M_{z}-y_{m} z_{m} M_{y} / I_{\omega}\right) \phi \\
A_{4}= & -\left(y_{m} M_{y}+z_{m} M_{z}+M_{w}\right) / I_{\omega} \\
& +\left(z_{m} M_{y}-y_{m} M_{z}\right) \phi / I_{\omega} \\
I_{\omega}= & I_{c}-y_{m}^{2} I_{y}-z_{m} I_{z}, C_{1}=1 / I_{z}+z_{m}^{2} / I_{\omega}
\end{aligned}
$$

および

$$
C_{2}=1 / I_{y}+y_{m}^{2} / I_{\omega}
$$

であり， $N, M_{y}, M_{z}, M_{w}$ および $\phi$ はそれぞれ収束計 算における 1 回前の断面力および断面回転角を表わす. また, 式（10）の右辺の第 1 式および第 2 式は［］で 区切られた第 1 項および第 2 項がそれぞれ対応してい る.

降伏断面を有するある格間から取り出した 微小要素 $d S_{0}$ について, 変形前の座標系に関する変位および断面 力を図一2に示す. 各断面力を式 (8) と同様な形式で, 便宜上名ゔけた “弾性項”および “非弾性項” の和とし て表わす.

$$
\left.\begin{array}{l}
\bar{H}=H+\Delta H, \quad \bar{B}_{x}=B_{x}+\Delta B_{x}, \bar{B}_{y}=B_{y}+\Delta B_{y} \\
\bar{B}_{z}=B_{z}+\Delta B_{z}, \quad \bar{B}_{w}=B_{w}+\Delta B_{w}
\end{array}\right\}
$$

微小要素 $d S_{0}$ について変形の増分を考慮して ${ }^{3)} x, y$ および $z$ 軸方向の力および $x, y$ および $z$ 軸まわりのモ 一メントのつり合い式を求めて次式のように整理する.

$$
\begin{aligned}
& \bar{H}^{\prime}=\left(V_{y} \cos \beta-V_{z} \sin \beta\right) / R \\
& V_{y^{\prime}}+\bar{H} \cos \beta / R=q_{z} \sin \beta+q_{Y} \cos \beta \\
& V_{z^{\prime}}-\bar{H} \sin \beta / R=q_{z} \cos \beta-q_{Y} \sin \beta \\
& \bar{B}_{x}{ }^{\prime}+\left(\bar{B}_{y} \cos \beta-\bar{B}_{z} \sin \beta\right) / R \\
& \quad+V_{y} \Omega-V_{z} \Psi=-t_{X}+m_{q} \\
& \bar{B}_{y^{\prime}}-\bar{B}_{x} \cos \beta / R+\bar{H} \Omega-V_{z}(1+\Pi)=0 \\
& \bar{B}_{z}{ }^{\prime}+\bar{B}_{x} \sin \beta / R-\bar{H} \Psi+V_{y}(1+I)=0
\end{aligned}
$$

ここに, $V_{y}$ および $V_{z}$ はそれぞれ $y$ および $z$ 軸方向 のせん断力である.また，

$$
\begin{aligned}
m_{q}= & q_{Y}\left\{\left(b_{Y}-Z_{c}\right)+\left(a_{Y}-Y_{c}\right) \theta\right\} \\
& -q_{Z}\left\{\left(a_{Z}-Y_{c}\right)+\left(b_{Z}-Z_{c}\right) \theta\right\}
\end{aligned}
$$

であり， $q_{Y}$ および $q_{Z}$ 海用点の $Y$ および $Z$ 座標が それぞれ $\left(a_{Y}, b_{Y}\right)$ および $\left(a_{Z}, b_{Z}\right)$ である $Y$ および $Z$ 軸方向の分布荷重であり， $t_{X}$ は分布ねじりモーメン
ト荷重である.

変形後の座標系に関する $\bar{B}_{\hat{\xi}}, \bar{B}_{\eta}$ および $\bar{B}_{;}$と変形前 の座標系に関する $\bar{B}_{x}, \bar{B}_{y}$ および $\bar{B}_{z}$ は次の関係式を 満足する.

$$
\left.\begin{array}{l}
\bar{B}_{x}=\bar{B}_{\xi}+\bar{B}_{\eta} \Psi+\bar{B}_{\zeta} \Omega, \bar{B}_{y}=\bar{B}_{\eta}-\bar{B}_{\zeta} \theta \\
\bar{B}_{z}=\bar{B}_{\zeta}+\bar{B}_{\eta} \theta
\end{array}\right\}
$$

$(13 \cdot a \sim c)$

微小変位理論によって求まる断面力を用いて式 (13) を線形化したのち, “弾性項” および “非弾性項”を分離 し,さらに $B_{\xi}, B_{\eta}$ および $B_{\zeta}$ に式 (8)，(10) を代入 すると，

$$
\begin{aligned}
B_{x}= & -E I_{c} \Theta^{\prime \prime}-y_{m} E I_{y}\left(\Omega^{\prime \prime}-\theta^{\prime} \cos \beta / R\right) \\
& +Z_{m} E I_{z}\left(\Psi^{\prime \prime}-\theta^{\prime} \sin \beta / R\right) \\
& +C_{T} \Theta+M_{\eta} \Psi+M_{\zeta} \Omega \\
B_{y}= & E I_{y}\left(\Omega^{\prime}+y_{m} \Theta^{\prime}-\theta \cos \beta / R\right)-M_{\zeta} \theta \\
B_{z}= & -E I_{z}\left(\Psi^{\prime}-z_{m} \Theta^{\prime}-\theta \sin \beta / R\right)+M_{\eta} \theta \\
\Delta B_{x}= & \Delta B_{\xi}+\Delta M_{\eta} \Psi+\Delta M_{\zeta} \Omega \\
\Delta B_{y}= & \Delta B_{\eta}-\Delta M_{\zeta} \theta \\
\Delta B_{z}= & \Delta B_{\zeta}+\Delta M_{\eta} \theta
\end{aligned}
$$

$(14 \cdot a \sim f)$

となる、

有限変位理論の場合の状態量ベクトルを弾性核の図心 に関する変形量および弾性項と名づけた断面力を用いて 次のように定義する.

$$
\begin{array}{r}
\boldsymbol{V}=\left\{v, \Psi, B_{z}, V_{y}, w, \Omega, B_{y}, V_{z}, \theta, \Theta, B_{w},\right. \\
\left.B_{x}, u, H\right\} \ldots \ldots \ldots \ldots \ldots \ldots \ldots \ldots \ldots \ldots \ldots \ldots \ldots \ldots \ldots \ldots \ldots \ldots
\end{array}
$$

状態量ベクトルに対する 1 階の連立微分方程式系を導 くために，まず，式 (1) および (8・a)より,

$$
\left.\begin{array}{rl}
u^{\prime} & =-H / E F_{e}+(v \cos \beta-w \sin \beta) / R \\
v^{\prime} & =\Psi-u \cos \beta / R \\
w^{\prime} & =\Omega+u \sin \beta / R \\
\theta^{\prime} & =\Theta-\Psi \sin \beta / R-\Omega \cos \beta / R
\end{array}\right\}
$$

$(16 \cdot a \sim d)$

式 $(8 \cdot \mathrm{d})$ および式 $(14 \cdot \mathrm{b}, \mathrm{c})$ より

$$
\begin{aligned}
\Theta^{\prime}= & -\left(y_{m} B_{y}+z_{m} B_{z}+B_{w}\right) / E I_{\omega} \\
& +\left(z_{m} M_{y}-y_{m} M_{z}\right) \theta / E I_{\omega} \\
& +\left(z_{m} M_{z}+y_{m} M_{y}\right) \theta^{2} / E I_{\omega}
\end{aligned}
$$

また, 式 $(16 \cdot \mathrm{e})$ の第 3 項を無視し, 式 $(14 \cdot b, c)$ に適 用すると，

$$
\left.\begin{array}{rl}
\Psi^{\prime}= & -C_{1} B_{z} / E-y_{m} z_{m} B_{y} / E I_{\omega}-z_{m} B_{w} / E I_{\omega} \\
& +\left(C_{1} M_{y} / E-y_{m} z_{m} M_{z} / E I_{\omega}+\sin \beta / R\right) \theta \\
\Omega^{\prime}= & C_{2} B_{y} / E+y_{m} z_{m} B_{z} / E I_{\omega}+y_{m} B_{w} / E I_{\omega} \\
& +\left(C_{2} M_{z} / E-y_{m} z_{m} M_{y} / E I_{\omega}+\cos \beta / R\right) \theta
\end{array}\right\}
$$

となる・

ここに, 式 $(16 \cdot \mathrm{e})$ は式 (13) から $\theta^{2}$ が十分小さい むのとして $M_{\eta}=M_{y}+M_{z} \theta, M_{\zeta}=M_{z}-M_{y} \theta$ を用いて 
導き, 第 3 項は他の項に比べて小さいので無視できるも のとする.

断面力については式 (12) の各式に式 (11) を考慮し, 非線形項には収束計算に扝ける 1 回前の断面力を用いて 線形化すれば,

$$
\begin{aligned}
H^{\prime}= & \left(V_{y} \cos \beta-V_{z} \sin \beta\right) / R \\
V_{y}{ }^{\prime}= & -H \cos \beta / R-\Delta H \cos \beta / R+q_{z} \sin \beta \\
& +q_{Y} \cos \beta \\
V_{z}{ }^{\prime}= & H \sin \beta / R+\Delta H \sin \beta / R+q_{z} \cos \beta \\
& -q_{Y} \sin \beta \\
B_{x}{ }^{\prime}= & \left(B_{z} \sin \beta-B_{y} \cos \beta\right) / R-Q_{y} \Omega+Q_{z} \Psi \\
& +\left\{q_{Y}\left(a_{Y}-Y_{c}\right)+q_{Z}\left(b_{Z}-Z_{c}\right)\right. \\
& \left.+\Delta M_{\zeta} \cos \beta / R+\Delta M_{\eta} \sin \beta / R\right\} \theta-t_{X} \\
& +q_{Y}\left(b_{Y}-Z_{c}\right)-q_{Z}\left(a_{Z}-Y_{c}\right) \\
& +\left(\Delta B_{\zeta} \sin \beta-\Delta B_{\eta} \cos \beta\right) / R-\Delta B_{x}{ }^{\prime} \\
B_{y}{ }^{\prime}= & B_{x} \cos \beta / R-N \Omega+V_{z}-Q_{z} H / E F_{e} \\
& -\Delta N \Omega+\Delta B_{x} \cos \beta / R-\Delta B_{y}{ }^{\prime} \\
B_{z}{ }^{\prime}= & -B_{x} \sin \beta / R+N \Psi-V_{y}+Q_{y} H / E F_{e} \\
& +\Delta N \Psi-\Delta B_{x} \sin \beta / R-\Delta B_{z}{ }^{\prime}
\end{aligned}
$$

となる.また，式 $(8 \cdot \mathrm{d})$ および式 $(14 \cdot \mathrm{a})$ から，

$$
B_{w}{ }^{\prime}=B_{x}-C_{T} \Theta-\Psi\left(M_{y}+M_{z} \phi\right)-\Omega\left(M_{z}-M_{y} \phi\right)
$$

となる.ここに, 式 (17·a) には $\Delta H^{\prime}=0$ を, 式 (17.

d) には式 $(14 \cdot \mathrm{e}, \mathrm{f})$ を, さらに式 $(17 \cdot \mathrm{e})$ および $(17 \cdot$

f）には式 (8・a) より $I I=-H / E F_{e}$ を用いた.

式 (17) で $\Delta B_{x}{ }^{\prime}, \Delta B_{y}{ }^{\prime}$ および $\Delta B_{z}{ }^{\prime}$ は式 (8)，(10) および（15）に仮定 (6) を用いて次のように表わされ る.

$$
\begin{aligned}
\Delta B_{x}{ }^{\prime}= & \theta^{\prime} \int_{P} \sigma_{Y} \operatorname{sgn}(\varepsilon)\left(y^{2}+z^{2}\right) d F \\
& +\Delta M_{\eta} \Psi^{\prime}+\Delta M_{\zeta} \Omega^{\prime} \\
\Delta B_{y^{\prime}}= & -\Delta M_{\zeta} \theta^{\prime}, \Delta B_{z}{ }^{\prime}=\Delta M_{\eta} \theta^{\prime}
\end{aligned}
$$

さらに， $\theta^{\prime}, \Psi^{\prime}, \Omega^{\prime}$ および $\theta^{\prime}$ に対して式 $(16 \cdot \mathrm{d} \sim \mathrm{g})$ を 代入して若干の計算の後, 式 $(17 \cdot d \sim f)$ は次のように 線形化される.

$$
\begin{aligned}
B_{x}{ }^{\prime}= & B_{y}\left\{-\frac{\cos \beta}{R}+\frac{y_{m}}{E I_{\omega}} K+\frac{y_{m} z_{m}}{E I_{\omega}} \Delta M_{\eta}-\frac{C_{2}}{E} \Delta M_{\zeta}\right\} \\
& +B_{z}\left\{\frac{\sin \beta}{R}+\frac{z_{m}}{E I_{\omega}} K-\frac{y_{m} z_{m}}{E I_{\omega}} \Delta M_{\zeta}+\frac{C_{1}}{E} \Delta M_{\eta}\right\} \\
& +B_{w}\left\{\frac{1}{E I_{\omega}} K-\frac{y_{m}}{E I_{\omega}} \Delta M_{\zeta}+\frac{z_{m}}{E I_{\omega}} \Delta M_{\eta}\right\}-\Omega Q_{y} \\
& +\Psi Q_{z}+\theta\left\{q_{Y}\left(a_{Y}-Y_{c}\right)+q_{z}\left(b_{z}-Z_{c}\right)\right. \\
& -\frac{z_{m} M_{y}-y_{m} M_{z}}{E I_{\omega}} K-\left(\frac{C_{2}}{E} M_{z}-\frac{y_{m} z_{m}}{E I_{\omega}} M_{y}\right) \\
& \left.+\Delta M_{\zeta}-\left(\frac{C_{1}}{E} M_{y}-\frac{y_{m} z_{m}}{E I_{\omega}} M_{z}\right) \Delta M_{\eta}\right\} \\
& -t_{X}+q_{Y}\left(b_{Y}-Z_{c}\right)-q_{Z}\left(a_{z}-Y_{c}\right)
\end{aligned}
$$

$$
\begin{aligned}
& +\frac{\Delta B_{\zeta} \sin \beta-\Delta B_{\eta} \cos \beta}{R} \\
B_{y}{ }^{\prime}= & B_{x} \frac{\cos \beta}{R}+V_{z}-H \frac{Q_{z}}{E F_{e}} \\
& -\Psi \frac{\Delta M_{\zeta} \sin \beta-\Delta M_{\eta} \cos \beta}{R}-\Omega(N+\Delta N) \\
& +\Theta\left(\Delta M_{\zeta}+\frac{\cos \beta}{R} K\right) \\
B_{z}{ }^{\prime}= & -B_{x} \frac{\sin \beta}{R}-V_{y}+H \frac{Q_{y}}{E F_{e}}-\Psi(N+\Delta N) \\
& +\Omega \frac{\Delta M_{\eta} \cos \beta-\Delta M_{\zeta} \sin \beta}{R} \\
& -\Theta\left(\Delta M_{\eta}+\frac{\sin \beta}{R} K\right)
\end{aligned}
$$

ここに, $K=\int_{P} \sigma_{Y} \operatorname{sgn}(\varepsilon)\left(y^{2}+z^{2}\right) d F$ である.

式 (15) の状態量ベクトル $\boldsymbol{V}$ を用いて式 (16)，(17) および (17)'を整理すると次式のように表わせる.

$$
\frac{d \boldsymbol{V}}{d S_{0}}=\boldsymbol{G} \boldsymbol{V}+\boldsymbol{H}
$$

ここに, $\boldsymbol{G}$ は格間内で $S_{0}$ の関数となる 14 行 14 列の 係数マトリックスであり，H 满重項ベクトルである.

式 (18) に Runge-Kutta 法を用いて格間 $k$ におい て数值積分を行うと, 次式を満足する格間伝達マトリッ クス $\boldsymbol{F}_{k}$ を数值的に得ることができる.

$$
\boldsymbol{V}_{k}{ }^{R}=\boldsymbol{F}_{k} \boldsymbol{V}_{k}{ }^{L}+\boldsymbol{L}_{k}
$$

ここに， $V_{k}{ }^{L}$ および $V_{k}{ }^{R}$ はそれぞれ格間 $k$ の左端お よび右端の状態量ベクトルを表わす．また， $L_{k}$ は格間 $k$ における荷重項を表わす。

\section{（3） 格点伝達マトリックス}

格間 $k$ の右端の状態量ベクトルを $\boldsymbol{V}_{k}{ }^{R}$ とし格間 $k$ +1 の左端のそれを $V_{k+1}{ }^{L}$ とすれば，それらは次式の ように結ばれる.

$$
\boldsymbol{V}_{k+1}{ }^{L}=\boldsymbol{P}_{k} V_{k}{ }^{R}+\boldsymbol{M}_{k}
$$

ここに， $\boldsymbol{P}_{k}$ 、格点伝達マトリックスとよばれ， $\boldsymbol{M}_{k}$ は 荷重項を表わすべクトルである.

a） 格点に集中荷重が作用する場合 ${ }^{3), 11)}$

格点 $k$ には，X,Y および $Z$ 軸方向の集中荷重 $P_{X}$, $P_{Y}$ および $P_{Z}$ が $Y-Z$ 座標でそれぞれ $\left(a_{X}, b_{X}\right),\left(a_{Y}\right.$ ， $\left.b_{Y}\right)$ および $\left(a_{Z}, b_{Z}\right)$ に作用しているものとする．格点 $k$ の左右の格間の弾性核は等しいものとし, 状態量べク トル $\boldsymbol{V}$ を変形量に関するべクトル $\boldsymbol{q}$ と断面力に関する ベクトル $\boldsymbol{Q}$ に分けると，変位の連続性から，

$$
\boldsymbol{q}_{k+1}{ }^{L}=\boldsymbol{q}_{k}{ }^{R}=\boldsymbol{q}_{k}
$$

が成り立ち, 断面力のつり合い条件式からは集中荷重に よる飛躍量を考慮して，

$$
\boldsymbol{Q}_{k+1}{ }^{L}=\boldsymbol{Q}_{k}{ }^{R}+\boldsymbol{T}_{k} \boldsymbol{q}_{k}{ }^{R}+\boldsymbol{U}_{k}
$$

が成り立つ.ここに， 


$$
\left.\begin{array}{rl}
\boldsymbol{q} & =\{v, \Psi, w, \Omega, \theta, \Theta, u\} \\
\boldsymbol{Q} & =\left\{V_{\boldsymbol{y}}, B_{z}, V_{z}, B_{y}, B_{x}, B_{w}, H\right\}
\end{array}\right\}
$$

であり， $\boldsymbol{T}_{k}$ および $\boldsymbol{U}_{k}$ の具体的な内容は文献 3）の值 に座標変換を行ったものである。

式（21）および（22）を式（20）の形式で整理すると， 格点伝達マトリックス $\boldsymbol{P}_{k}$ を得る.

b）格点 $k$ の左右の格間における弾性核が異なる場 合 ${ }^{12)}$

解析には仮定 (6) の近似を用いるため格点において弾 性核が不連続になることは避けられない。このような場 合の格点伝達式を求める.

図一2 で定義した $X-Y-Z$ 座標に関する格間 $k$ （格 点 $k$ の左側）の弾性核の図心 $\mathrm{C}$ の座標および主軸方向 をそれぞれ添字 $l$ をつけて $C_{l}\left(Y_{c l}, Z_{c l}\right)$ および $\beta_{l}$ と し, 格間 $k+1$ (格点 $k$ の右側) のそれらには添字 $r$ を つけて $C_{r}\left(Y_{c r}, Z_{c r}\right)$ および $\beta_{r}$ とする.ここで, 図一 3 に示すように原点を $Y-Z$ 座標に一致させた格点 $k$ の 主軸方向の座標系 ( $\bar{y}-\bar{z}$ 座標) を定めて, この座標に関 する前述の図心座標をそれぞれ $C_{l}\left(\bar{y}_{c l}, \bar{z}_{c l}\right)$ および $C_{r}$ $\left(\bar{y}_{c r}, \bar{z}_{c r}\right)$ とすれば次式が成り立つ.

$$
\begin{aligned}
& \bar{y}_{c l}=Y_{c l} \cos \beta_{l}+Z_{c l} \sin \beta_{l} \\
& \bar{z}_{c l}=-Y_{c l} \sin \beta_{l}+Z_{c l} \cos \beta_{l} \\
& \bar{y}_{c r}=Y_{c r} \cos \beta_{l}+Z_{c r} \sin \beta_{l} \\
& \bar{z}_{c r}=-Y_{c r} \sin \beta_{l}+Z_{c r} \cos \beta_{l}
\end{aligned}
$$

断面上の任意の 2 点 $\left(\bar{y}_{1}, \bar{z}_{1}\right)$ および $\left(\bar{y}_{2}, \bar{z}_{2}\right)$ につい て, 式 (2) に関する変位の連続性を考慮すると,

$$
\left.\begin{array}{l}
v_{1}=v_{l}-\left(\bar{z}_{1}-\bar{z}_{c l}\right) \theta_{l}=v_{r} *-\left(\bar{z}_{1}-\bar{z}_{c r}\right) \theta_{r} * \\
v_{2}=v_{l}-\left(\bar{z}_{2}-\bar{z}_{c l}\right) \theta_{l}=v_{r} *-\left(\bar{z}_{2}-\bar{z}_{c r}\right) \theta_{r} *
\end{array}\right\}
$$

となる.ここに，*印は格点 $k$ の左側の弾性核の主軸 ( $\bar{y}, \bar{z}$ 軸) 方向で表わした図心 $C_{r}$ の変形量を意味す

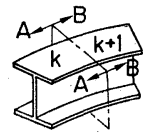

\section{Yielded Portion}

SECTION A-A

SECTION B-B

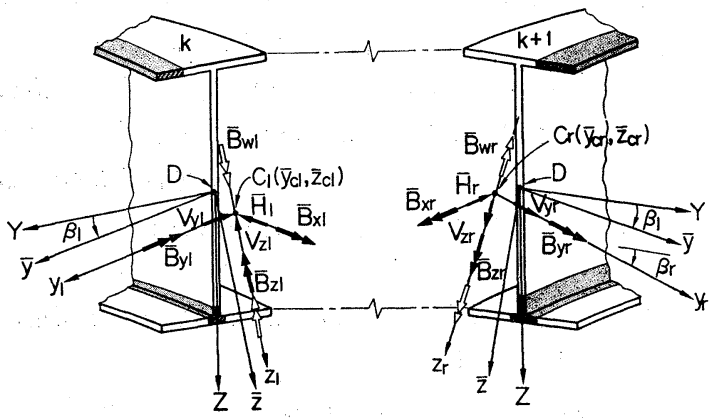

図一3 格点の左右における断面力
る.

式 $(24 \cdot \mathrm{a})$ と $(24 \cdot \mathrm{b})$ の辺々を差し引くと， $\theta_{r} *=\theta$

が得られ，式（25）を式（24）に代入して次式を得る. $v_{r}^{*}=v_{l}-\Delta \bar{z}_{c} \theta_{l}, \Delta \bar{z}_{c}=\bar{z}_{c r}-\bar{z}_{c l}$

また，wについても同様な結果が得られる。

$w_{r}^{*}=w_{l}+\Delta \bar{y}_{c} \theta_{l}, \Delta \bar{y}_{c}=\bar{y}_{c r}-\bar{y}_{c l}$

$\bar{y}-\bar{z}$ 座標の原点 $\mathrm{D}$ 関するそり関数を $\varphi_{D}$ とすれば, 図心 C に関するそり関数 $\varphi_{c}$ は,

$$
\varphi_{c}=\varphi_{D}+\bar{z}_{c} \bar{y}-\bar{y}_{c} \bar{z}
$$

となり ${ }^{9), 12)}$ ，任意の 2 点について式 (2・a) に式 (28) を 用い, 変位の連続性を考慮することにより式 (24)〜 (27) と同様な展開を行うことができ，次式を得る ${ }^{12)}$

$$
\left.\begin{array}{l}
\Theta_{r} *=\Theta_{l}, \Psi_{r} *=\Psi_{l}-\Delta \bar{z}_{c} \Theta_{l}, \Omega_{r} *=\Omega_{l}+\Delta \bar{y}_{c} \Theta_{l} \\
u_{r} *=u_{l}-\Delta \bar{y}_{c} \Psi_{l}-\Delta \bar{z}_{c} \Omega_{l}+\Phi_{D} \Theta_{l}
\end{array}\right\}
$$

ここに, $\Phi_{D}=\varphi_{D r i}-\varphi_{D l i}+\Delta \bar{z}_{c} \bar{y}_{c r}-\Delta \bar{y}_{c} \bar{z}_{c r}$ であり, $\varphi_{D l i}$ および $\varphi_{D r i}$ はそれぞれ格点 $k$ の左側および右側 の弾性核について求めた点 $i$ の単位そりである.

式 (27) 〜 (34) で得られた $\theta_{r} * \sim u_{r} *$ に座標変換を行 う格点 $k$ の右側の断面 (弾性核) の主軸方向に関す る変形量が求まる.

$$
\left.\begin{array}{rl}
\theta_{r} & =\theta_{l} \\
v_{r} & =v_{l} \cos \gamma+w_{l} \sin \gamma-\theta_{l} \Delta_{1} \\
w_{r} & =w_{l} \cos \gamma-v_{l} \sin \gamma+\theta_{l} \Delta_{2} \\
u_{r} & =u_{l}-\Psi_{l} \Delta \bar{y}_{c}-\Omega_{l} \Delta \bar{z}_{c}+\Theta_{l} \Phi_{D} \\
\Psi_{r} & =\Psi_{l} \cos r+\Omega_{l} \sin r-\Theta_{l} \Delta_{1} \\
\Omega_{r} & =\Omega_{l} \cos \gamma-\Psi_{l} \sin \gamma+\Theta_{l} \Delta_{2} \\
\Theta_{r} & =\Theta_{l}
\end{array}\right\} \cdots(30 \cdot \mathrm{a} \sim \mathrm{g})
$$

ここに, $\gamma=\beta_{r}-\beta_{l}, \Delta_{1}=\Delta \bar{z}_{c} \cos \gamma-\Delta \bar{y}_{c} \sin \gamma$ および $\Delta_{2}$ $=\Delta \bar{y}_{c} \cos \gamma+\Delta \bar{z}_{c} \sin \gamma$ であり, 式（30）は格点の左右 で弾性核が異なる場合の変形量に関する格点伝達方程式 である。

一方，断面力に関寸る格点伝達方程式は文献 12) のよ らに仮想変位の原理を適用して導くことができ, 次式を 得る.

$$
\begin{aligned}
& -\bar{B}_{x l}+V_{y r} \Delta_{1}-V_{z r} \Delta_{2}+\bar{B}_{x r}=0 \\
& -\bar{B}_{y l}-\bar{B}_{z r} \sin r+\bar{B}_{y r} \cos r+\bar{H}_{r} \Delta \bar{z}_{c}=0 \\
& \bar{B}_{z l}-\bar{B}_{z r} \cos r-\bar{B}_{y r} \sin r+\bar{H}_{r} \Delta y_{c}=0 \\
& V_{y l}-V_{y r} \cos \gamma+V_{z r} \sin r=0 \\
& V_{z l}-V_{y r} \sin r-V_{z r} \cos \gamma=0 \\
& \bar{B}_{w l}+\bar{B}_{z r} \Delta_{1}+\bar{B}_{y r} \Delta_{2}-\bar{B}_{w r}-\bar{H}_{r} \Phi_{D}=0 \\
& \bar{H}_{l}-\bar{H}_{r}=0
\end{aligned}
$$

式 $(14 \cdot \mathrm{d} \sim \mathrm{f})$ に式 (30) を代入して得られる格点 $k$ の左右のそれぞれの “非弾性項” と式 (11) を用いて式 (31) より若干の計算の後, 断面力に関する格点伝達方程 
式を次のように得る.

$$
\begin{aligned}
B_{z r}= & B_{z l} \cos r-B_{y l} \sin \gamma+H_{l} \Delta_{2} \\
& +\theta_{l}\left(\Delta M_{\eta l} \cos r-\Delta M_{\eta r}+\Delta M_{\zeta l} \sin r\right) \\
& +\Delta B_{\zeta l} \cos r-\Delta B_{\zeta r}-\Delta B_{\eta l} \sin \gamma+\Delta H_{l} \Delta_{2} \\
V_{y r}= & V_{y l} \cos \gamma+V_{z l} \sin r \\
V_{z r}= & V_{z l} \cos r-V_{y l} \sin r \\
B_{y r}= & B_{z l} \sin r+B_{y l} \cos r-H_{l} \Delta_{1} \\
& +\theta_{l}\left(\Delta M_{\eta l} \sin r+\Delta M_{\zeta r}-\Delta M_{\zeta l} \cos \gamma\right) \\
& +\Delta B_{\zeta l} \sin r-\Delta B_{\eta r}+\Delta B_{\eta l} \cos \gamma-\Delta H_{l} \Delta_{1} \\
B_{w r}= & B_{w l}+B_{z l} \Delta \bar{z}_{c}+B_{y l} \Delta \bar{y}_{c}-H_{l} \Phi_{D} \\
& +\theta_{l}\left(\Delta M_{\eta l} \Delta \bar{z}_{c}-\Delta M_{\zeta l} \Delta \bar{y}_{c}\right)+\Delta B_{w l} \\
& -\Delta B_{w r}+\Delta B_{\zeta l} \Delta \bar{z}_{c}+\Delta B_{\eta l} \Delta \bar{y}_{c}-\Delta H_{l} \Phi_{D} \\
B_{x r}= & B_{x l}+V_{z l} \Delta \bar{y}_{c}-V_{y l} \Delta \bar{z}_{c}-\Theta_{l}\left(\Delta M_{\zeta r} \Delta_{2}\right. \\
& \left.-\Delta M_{\eta r} \Delta_{1}\right)+\Psi_{l}\left(\Delta M_{\eta l}-\Delta M_{\eta r} \cos \gamma\right. \\
& \left.+\Delta M_{\zeta r} \sin \gamma\right)+\Omega_{l}\left(\Delta M_{\zeta l}-\Delta M_{\eta r} \sin r\right. \\
& \left.-\Delta M_{\zeta r} \cos \gamma\right)+\Delta B_{\xi l}-\Delta B_{\xi r} \\
H_{r}= & H_{l}+\Delta H_{l}-\Delta H_{r}
\end{aligned}
$$

式（30）および式（32）は, 式 (20) の形式に整理す ることができ, 得られるマトリックス $\boldsymbol{P}_{k}$ およびベクト ル $\boldsymbol{M}_{k}$ はそれぞれ格点 $k$ の左右で弾性核が異なる場合 の格点伝達マトリックスおよび荷重項ベクトルである.

\section{（4）計算方法}

伝達マトリックスによる解析法は文献 11) によること とし, 本節では図一 4 に示す曲線ばりの弾塑性有限変位 解析のフローチャートについて説明する。

(a) 微小変位理論による解析（図一4 (4)）

(b) 有限変位理論による解析（図一-4 (3) (5) (6) (7) (8))

(6)における変形量に対する収束計算の誤差は $1 \%$ とした.

(C) 弾塑性域における断面諸量の決定（図-4 (9) (10) (11))

変形量が収束した場合，格間ごとに図一1に示し た微小断面要素の垂直ひずみ $\varepsilon_{i}$ を式 (5) より求め る. このとき要素 $i$ の応力 $\sigma_{i}$ は仮定 (5) および (7) より,

$$
\left.\begin{array}{ll}
\sigma_{i}=E \varepsilon_{i} & \left(\left|\varepsilon_{i}\right|<\varepsilon_{Y}\right) \\
\sigma_{i}=\sigma_{Y} \cdot \operatorname{sgn}\left(\varepsilon_{i}\right) & \left(\left|\varepsilon_{i}\right| \geqq \varepsilon_{Y}\right)
\end{array}\right\}
$$

となるが, その応力分布から計算される断面力と, すでに収束計算で求まっている断面力は一致しな い. 吉田ら ${ }^{13)}$ はひずみを修正して断面力を収束させ ているが, 本研究においては収束計算の 1 サイクル ごとに新たに降伏を認める微小要素の数を垂直ひず みの大きい方から 3 個（全要素数の 20 分の 1 ）ま でとし，急激に誤差が生ずることを避けた.

断面から降伏した微小断面要素を取り除いてでき

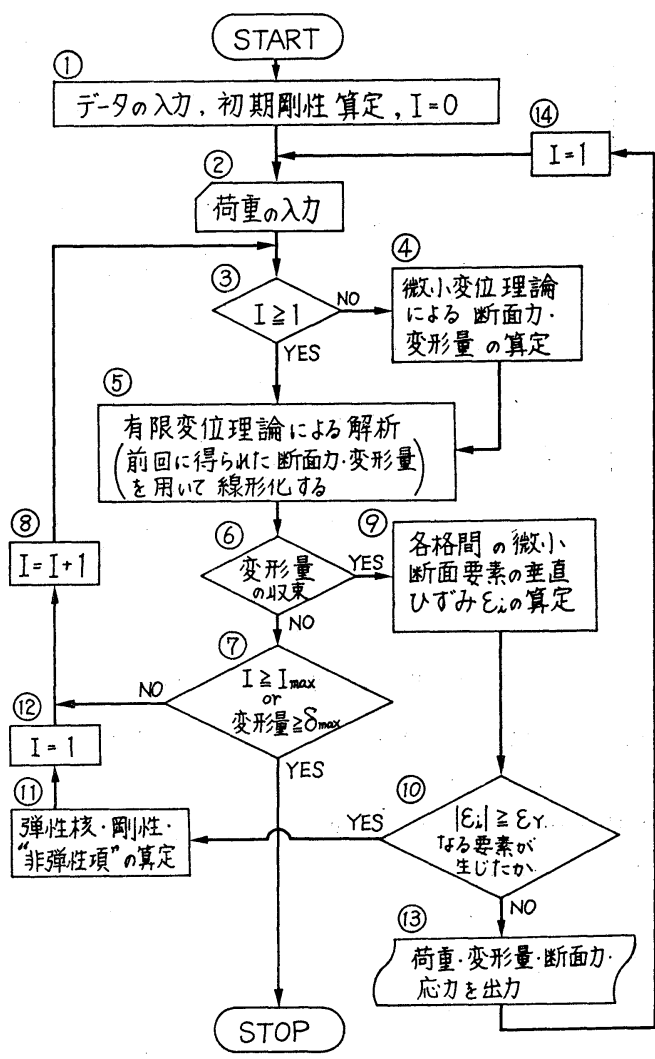

図一4 フローチャート

る弾性核について, 式 (6) の断面定数等を定める.

一方, 降伏部分については式 (8) および (10) に示

した“非弾性項”の値を定める.

(d) 荷重の増加（図一4 (10) (13) (14) (2)

ある荷重について, 変形量が収束し, かつ新らた な降伏断面要素が生じないとき, 次の荷重について 計算を行ら.

(e) 計算の打切り（図-4 (7)

変形量が収束しなくなったとき, あるいは変形量 が過大になったとき計算を打切る.

\section{3. 数値計算結果}

\section{（1）実験值との比較}

本解析法の妥当性を検討するために実験值との比較を 行った. 実験值は福本ら ${ }^{15)}$ の溶接 I 形曲線ばりの耐荷力 実験結果である. 図一5 はその一例であり，スパン中央 における断面回転角 $\theta$ と荷重 $P$ の関係を示している. なお，供試体の諸元は，曲線スパン長 $L_{s}=2.8 \mathrm{~m}$, 曲 率半径 $R=35 \mathrm{~m}$, 偏心量 $f / L_{s} \fallingdotseq 1 / 100$, ヤング率 $E=$ $2.1 \times 10^{6} \mathrm{~kg} / \mathrm{cm}^{2}(206 \mathrm{GPa})$ および降伏応力度 $\sigma_{Y}=3200$ 


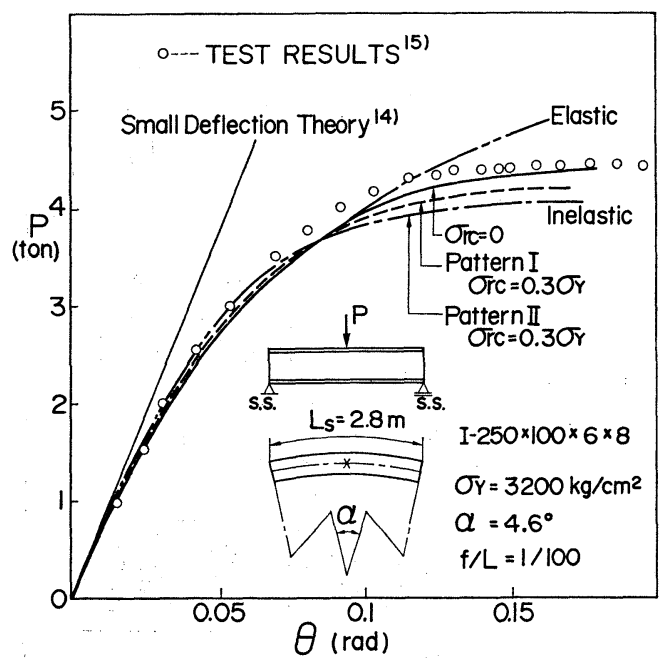

図一5 荷重と断面回転角の関係

$\mathrm{kg} / \mathrm{cm}^{2}$ (314 MPa) であり，荷重はスパン中央で上フラ ンジ中央に載荷されている.

計算は 図一1に示した残留応力分布を仮定し，格閒要 素数を 12 (集中荷重であることから格間長は $0.1 \sim 0.4$ m. に分割した）とした. また Runge-Kutta 法による数 值積分の分割数は 3 とした. その結果, 変形量に関する 収束は耐荷力近くで悪くなるが，3〜4 回程度の繰り返 し計算で所定の精度を得た. 図一5 より, 用いた例では 残留応力が耐荷力に及ぼす影響は小さいよらであり数值 計算結果注実験值をよく表わしている. 他の供試体につ いてもほぼ満足のいく計算結果を得ている ${ }^{17)}$.

\section{（2）耐荷力曲線について}

横方向およびねじりについても両端で単純支持された 直線ばりの横倒れ座屈強度は次式で表わされ る.

$$
M_{c r}=C \frac{\pi}{L} \sqrt{E I_{z} G K_{T}\left(1+\frac{\pi^{2} E I_{\omega}}{G K_{T} L^{2}}\right)}
$$

ここに，L はスパン長であり, $E I_{z}, G K_{T}$ および $E I_{\omega}$ はそれぞれ弱軸まわりの曲げ剛 性, St. Venant のねじり剛性およびそり剛 性である。また，Cは荷重状態によって決ま る係数である ${ }^{18)}$.

本研究においては, 曲線ばりの耐荷力曲線 を直線ばりの横倒れ座屈曲線に通常用いられ ているパラメーター $\left(\delta_{r}-\bar{\lambda}\right)$ で整理し，さ らに円曲線を表わすパラメーターとして中心 角 $\alpha$ を選んだ. $\delta_{r}$ および

$$
\delta_{r}=M_{U} / M_{P}, \bar{\lambda}=\sqrt{M_{P} / M_{E}} \cdots
$$

のように表わされる.ここに， $M_{U}, M_{P}$ お
よび $M_{E}$ はそれぞれ耐荷力，全塑性モーメントおよび 断面の困心を通る曲線軸に沿って測ったスパン長 $L_{S}$ を式（34）に代入して得られる弾性座屈モーメントであ る. 集中荷重および等分布荷重の場合の $M_{U}$ はそれぞ れスパン長 $L_{s}$ を用いて $P_{U} \cdot L_{s} / 4$ および $q_{U} \cdot L_{s}{ }^{2} / 8$ と した.

以下の数值計算例に用いる I 形断面は断面の高さ, フ ランジ幅, ウェブ厚さおよびフランジ厚さがそれぞれ, $200 \mathrm{~mm}, 100 \mathrm{~mm}, 5.6 \mathrm{~mm}$ および $8.5 \mathrm{~mm}$ の断面 (IPE 200 , 以後 SECTION A とよぶ) と $600 \mathrm{~mm}, 220 \mathrm{~mm}$, $12 \mathrm{~mm}$ および $19 \mathrm{~mm}$ の断面 (IPE 600, 以後 SECTION B とよぶ）の 2 種である. 鋼 I 形断面桁の横倒れ座屈強 度に関する実験資料（文献 16））によれば，圧延断面お よび Beam Type に属する溶接断面では，ごく一部を 除き, ウェブ高とフランジ幅の比 $h / b=2.0 \sim 3.0$ のも のについて実験されている. 特に, わが国で行われた多 くの圧延断面 $(\mathrm{I}-200 \times 100 \times 5.5 \times 8)$ は IPE 200 に類 似していることから，IPE 断面（DIN 1025）にあって は比較的ウェブ高の低い IPE $200(h / b=2.0)$ および最 もウェブ高の高い IPE $600(h / b=2.73)$ を数值計算に用 いることにした．この 2 断面は，通常用いられる Beam Type の断面を包含するものといってもよく，ここに示 す耐荷力曲線は通常用いられる Beam Type の断面を 有するはりの耐荷力曲線に関する特性を包含しているも のと思われる.

図一6 注計算に用いた 2 種類の断面を有するはりの偏 心量 $f$ を示している. 円曲線を表わすパラメーターを ๙とした場合， $\alpha$ が同じであっても荷重状態，断面およ

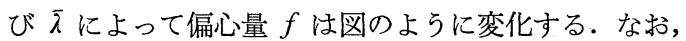
$\alpha=0.5^{\circ}(0.009 \mathrm{rad}), 5^{\circ}(0.087 \mathrm{rad})$ および $10^{\circ}(0.174$

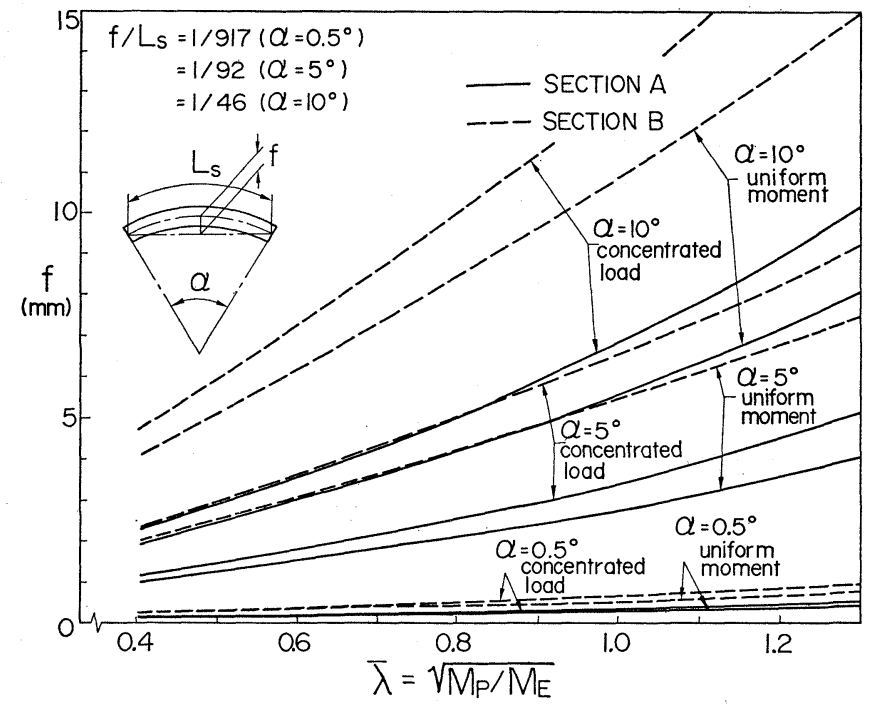

図一6 曲線ばりの偏心量 $\boldsymbol{f}$ 
rad) に対してそれぞれ $f / L_{s}=1 / 917,1 / 92$ および $1 / 46$ となる。

図一7 および 8 は圧延型残留応力 (Pattern I) を有 する SECTION A と SECTION B の耐荷力曲線であ り，それぞれ集中荷重および等曲げの場合である. 集中 荷重はスパン中央断面の図心に載荷し, モーメント荷重 は曲率半径方向にはりの両端で作用させた. なお, 各図 中の実験值 ${ }^{15), 16)}$ は, 荷重条件および境界条件を考慮し

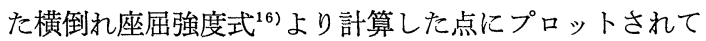
いる. 図から断面の違いによる耐荷力曲線の差は一様な 傾向を示し SECTION B が常に低くなる.これは断面 寸法はもちろんのこと偏心量の差も一因であると思われ る.また, 図一8に示した一点鎖線は ECCS (European Convention for Constructional Steelwork) の横倒れ座

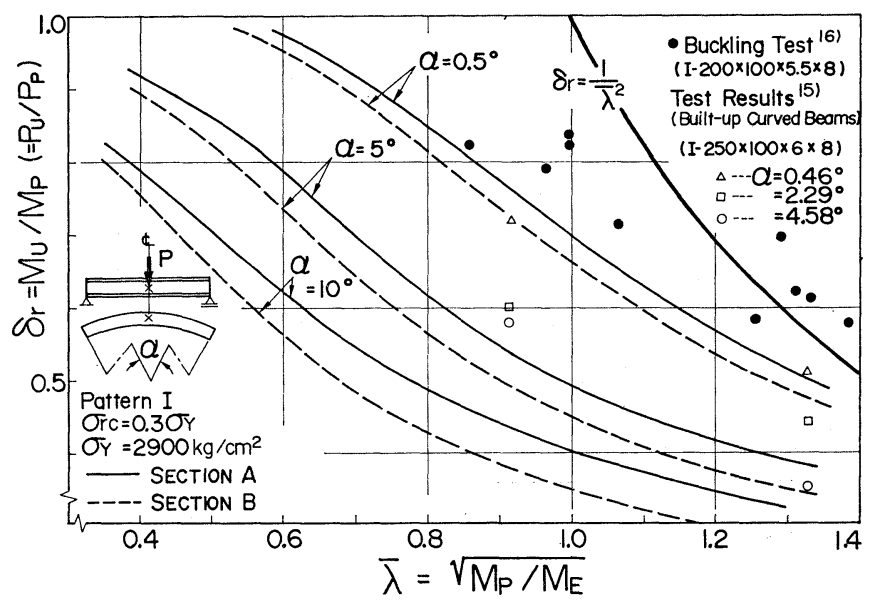

図一7耐荷力曲線（集中荷重）

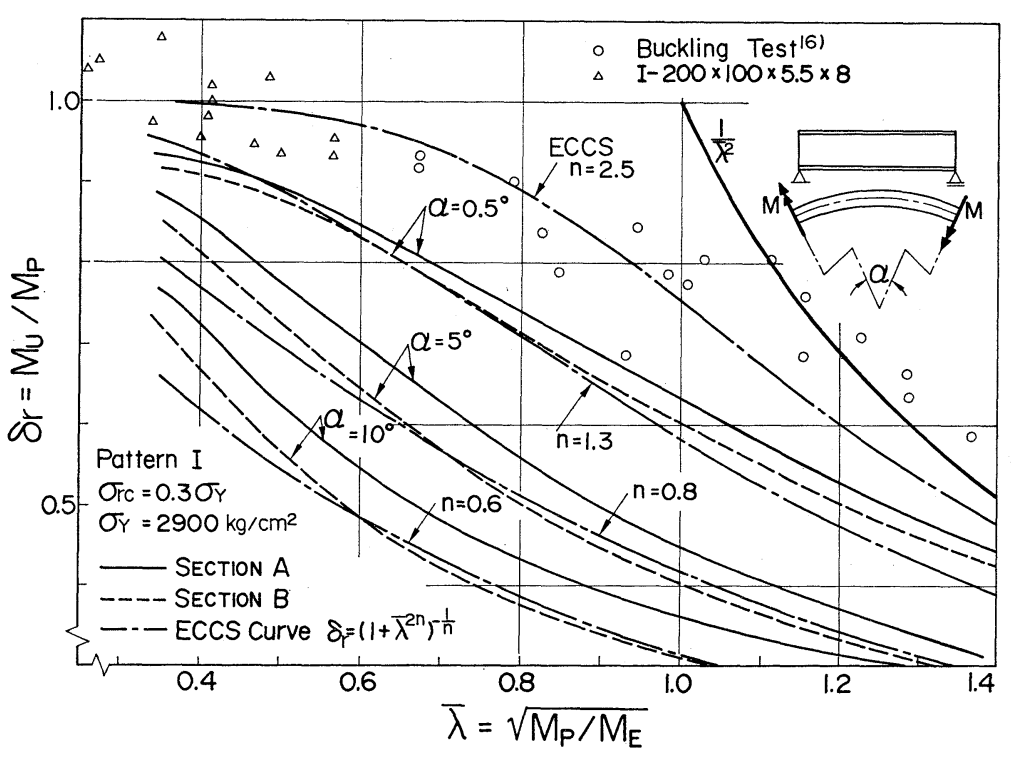

図一8 耐荷力曲線（一様曲げモーメント）
屈強度の提案式 $\delta_{r}=\left(1+\bar{\lambda}^{2 n}\right)^{-1 / n}$ の $n$ を適当に選び計 算結果を近似的に表わしたものである.

図一9 は SECTION A を対象として荷重状態の違い による耐荷力曲線の相違を示している， $\alpha$ および 小さいほど耐荷力曲線に差が大きく現われる．これは降 伏域のスパン方向への広がりの程度の差が一因と思われ る. すなわち, 集中荷重の場合にはスパン中央付近だけ 降伏域が生じ, 剛性の低下が小さいためと思われる.

図一10 は耐荷力に及ぼす残留応力の影響を検討する ために, SECTION A の部材に 図一1 に示す $2 つ$ 残 留応力分布型を用い, 残留応力の大きさを変えたときの 一様曲げに対する耐荷力曲線を比較したものである. 中 心角 $\alpha$ が大きくなると残留応力の分布型および大きさの 影響は小さくなっている. ただし， $\alpha=0.5^{\circ}$ の場合に は Pattern I と Pattern II の差および Pattern II であっても最大圧縮残留応力 $\sigma_{r c}$ の大きさによる差が顕著である. また, Pattern II $\left(\sigma_{r c}=0.5 \sigma_{Y}\right)$ の場合には, $\bar{\lambda}<0.45$ において $\alpha=5^{\circ}$ の耐荷力と $\alpha=0.5^{\circ}$ の耐荷 力とが逆転している.これは 図一11 に示す ように部材の降伏域の広がり方が大きく影響 しているものと思われる。

図一11 は $\bar{\lambda}=0.378\left(L_{s}=0.8 \mathrm{~m}\right)$ で Pattern II $\left(\sigma_{r c}=0.5 \sigma_{Y}\right)$ の残留応力を有する $\alpha=0.5^{\circ}$ および $5^{\circ}$ の SECTION A 部材に モーメント荷重 $M=4.8 \mathrm{t} \cdot \mathrm{m}(47 \mathrm{kN} \cdot \mathrm{m})(M /$ $\left.M_{P}=0.789\right)$ が作用する場合の降伏状況を示 している. $\alpha=0.5^{\circ}$ と $5^{\circ}$ ではそり応力の大 きさが異なること，およびはり両端のモーメ ント荷重の作用方向が同じでない ことが図のような降伏域の相違を 生ぜしめ, その結果, 耐荷力の逆 転にまで影響を及ぼしているもの と思われる。

\section{4. 結語}

本研究においては，まず，曲線 I 形ばりの有限変位弾塑性解析に 伝達マトリックス法を適用する方 法について示した. 次に, これを 用いて曲線 I 形ばりの耐荷力曲線 の性状について検討を行った. 得 られたおもな結果は次のとおりで ある。

（1）本解析法の妥当性は実験 值との比較により検証できた．た 

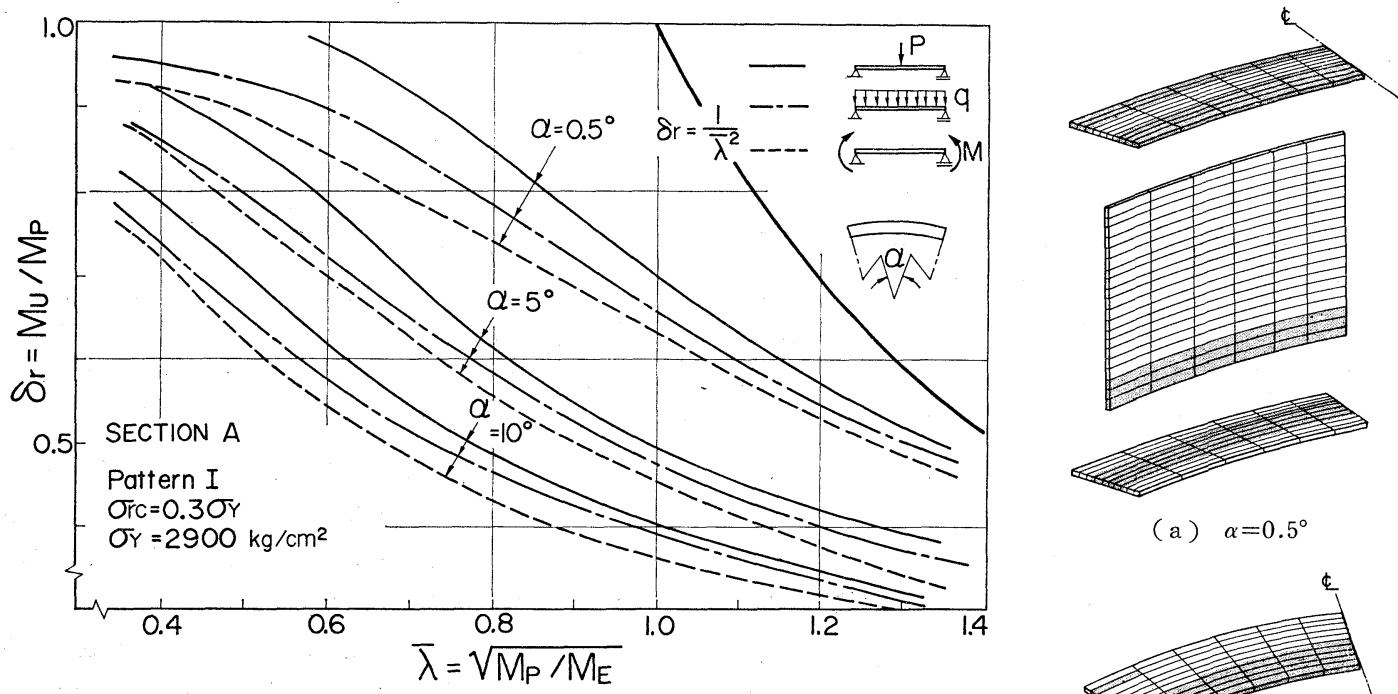

(a) $\alpha=0.5^{\circ}$

図一9 耐荷力曲線（荷重による比較）
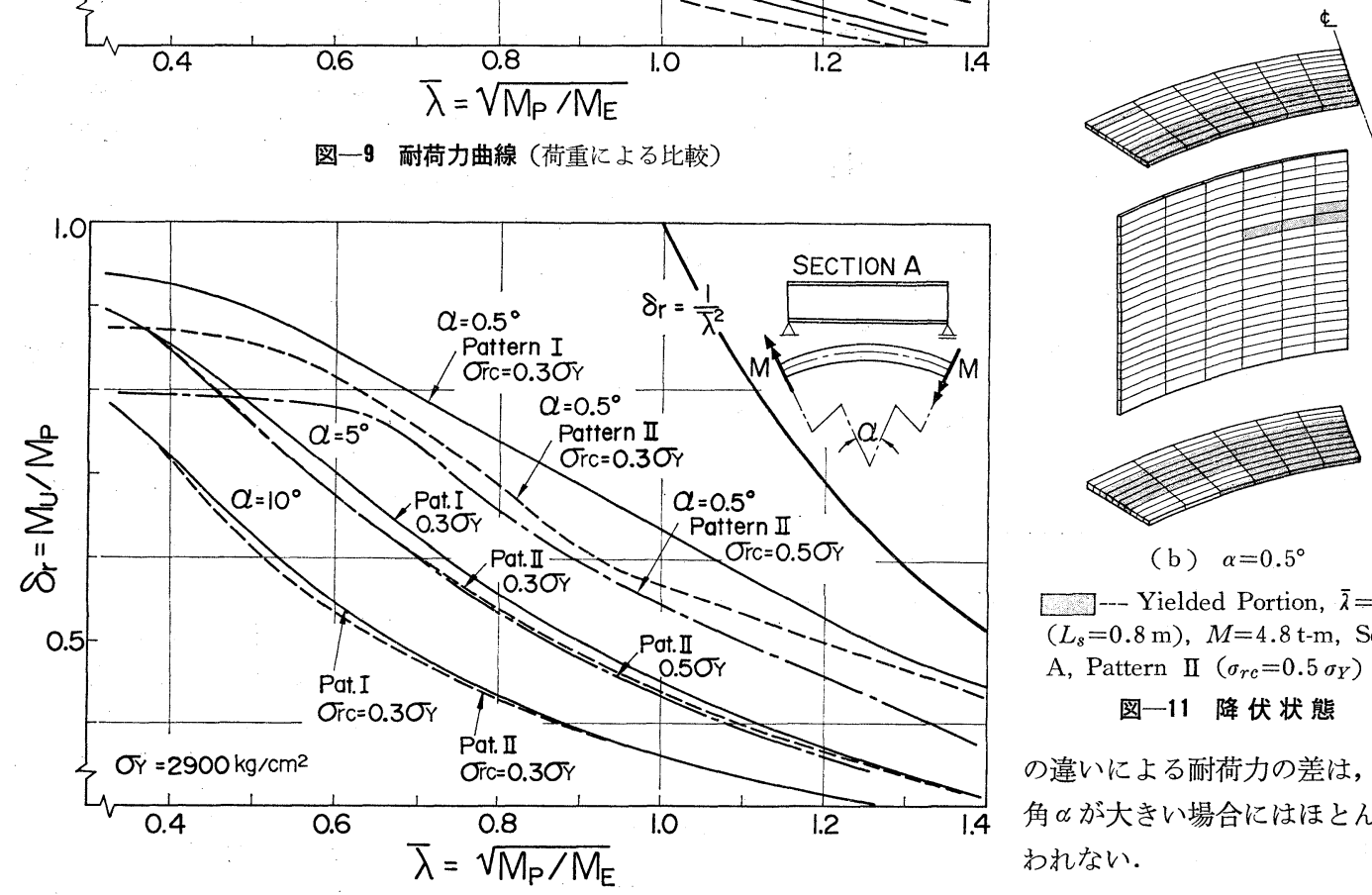

(b) $\alpha=0.5^{\circ}$

--- Yielded Portion, $\bar{\lambda}=0.378$ $\left(L_{s}=0.8 \mathrm{~m}\right), M=4.8 \mathrm{t}-\mathrm{m}$, Section A, Pattern II $\left(\sigma_{r c}=0.5 \sigma_{Y}\right)$

图一11降伏状態

の違いによる耐荷力の差は, 中心 角 $\alpha$ が大きい場合にはほとんど現 われない。

図一10 耐荷力曲線（残留応力による比較）

だし，実験值は集中荷重を載荷した 6 供試体だけであ り，降伏域も部分的であることから異なった荷重状態に よる実験值との比較検討も今後行う予定である.

（2）圧延型残留応力 (Pattern I) 定有する曲線 I 形ばりの場合, 式 (35) の $\left(\delta_{r}-\bar{\lambda}\right)$ および中心角 $\alpha$ を パラメーターとして耐荷力曲線を描くと, 荷重状態およ び断面によって差はあるものの滑らかな曲線になる.な お, $\operatorname{ECCS}$ の横倒れ座屈強度の提案式は $n$ を適当に選ぶ ことにより耐荷力曲線の近似式になり得る.

（3） $\bar{\lambda}$ が小さい範囲では荷重状態によって耐荷力曲 線に差が現われる.これは, 偏心量 $f$ および降伏域の 広がりの程度に差があるためと思われる.

(4) 残留応力の分布型および最大圧縮残留応力 $\sigma_{r c}$

実験值との比較において実験值を提供していただいた 名古屋大学 福本唀士教授ならびに金沢工業大学 西田 進教授に厚く御礼申し上げます，なお，本研究の数值計 算には金沢大学計算機センターの FACOM-M 160 を使 用し，図面のトレースにあたっては金沢大学工学部構造 力学研究室の井原朋美技官にお世話になった.

参 考 文 献

1）西野文雄 : 倉方慶夫・長谷川彰夫・奥村敏恵 : 軸力と曲 げおよびねじりを受ける薄肉断面部材，土木学会論文報 告集, 第 225 号, pp. 1 15, 1974 年 4 月.

2）西野文雄・深沢泰晴 : ひずみ場の仮定に基ゔく薄肉曲が りばりの静的挙動の定式化, 土木学会論文報告集, 第 247 号, pp. 9 19, 1976 年 3 月.

3）遠田良喜：伝達マトリックス法による薄肉開断面曲線ば りの有限変位理論の解析, 土木学会論文報告集, 第 199 
号, pp. $11 \sim 20,1972$ 年 3 月.

4) 薄木征三・稼農知徳・渡辺 昇: 有限な权じれを考虑し た薄肉曲線部材の変形解析, 土木学会論文報告集, 第 290 号, pp. 1 15，1979 年 10 月.

5）遠田良喜：伝達マトリックスとその応用に関する研究， 名古屋大学学位論文, 論工博第 159 号, 1973 年 3 月.

6）樑沢泰晴: 薄肉曲線材の静力学的解析に関する基礎的研 究, 土木学会論文報告集, 第 110 号, pp. 30 51, 1964 年 10 月.

7）薄木征三：変形を考慮した薄肉断面円弧アーチの曲げね じれ座屈, 土木学会論文報告集, 第 263 号, pp. 35 48, 1977 年 7 月.

8）遠田良喜：伝達マトリックス法による薄肉開断面曲線ば りの 2 次応力問題の解析, 土木学会論文報告集, 第 210 号, pp. 1 11, 1973 年 2 月.

9）高岡宣善: 構造部材のねじり解析, 共立出版, 1975 年.

10） Galambos, T.V. (福本唀士・西野文雄共訳)：鋼構造部 材と骨組一強度と設計, 丸善, 1970 年.

11）成岡昌夫・遠田良喜 : 伝達マトリックス法・コンピュー 夕による構造工学講座 I-2-B, 培風館, 1974 年.

12) Becker, G. : Ein Beitrag zur statischen Berechnung beliebig gelagerter ebener gekrümmter Stabe mit einfach symmetrischen dünnwandigen offenen Profilen von in Stabachse veränderlichem Querschnitt under
Berücksichtigung der Wölbklafttorsion, Der Stahlbau, Heft 11, pp. 334 346, Nov. 1965.

13）吉田 博・井本芳宏 : 拘束を受けるはりの弾性および非 弾性横倒れ座屈解析, 土木学会論文報告集, 第 208 号, pp. 1 12, 1972 年 12 月.

14）島田静雄・倉西 茂: 曲がりばりの計算式, 技報堂, 1966 年.

15）福本唀士・西田 進 : 曲線 I 形梁の 耐荷力実験, 土木学 会中部支部研究発表会講演概要集, 1979 年 2 月.

16) Fukumoto, Y. and M. Kubo : An Experimental Review of Lateral Buckling of Beams and Girders, International Colloquim on Stability of Structures under Static and Dynamic Loads, ASCE, pp. 541 562,1977 .

17）吉田 博・前川幸次 : 薄肉開断面曲線ばりの弾塑性解析 について, 土木学会第 34 回年次講演会概要集 I-105, 1979 年 10 月.

18）小堀為雄・吉田 博 : 鋼構造設計理論, 森北出版, 1977 年.

19) Vlassov, V.Z. (奥村敏恵ほか共訳)：薄肉弾性ばりの理 論, 技報堂, 1967 年.

(1980.5.19 · 受付) 